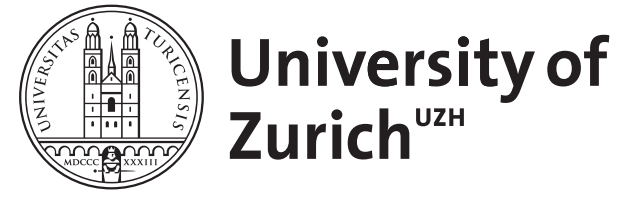

\title{
George Rosen as I knew him
}

Ackerknecht, Erwin H

DOI: https://doi.org/10.1093/jhmas/xxxiii.3.254

Posted at the Zurich Open Repository and Archive, University of Zurich ZORA URL: https://doi.org/10.5167/uzh-154225

Journal Article

Published Version

Originally published at:

Ackerknecht, Erwin H (1978). George Rosen as I knew him. Journal of the History of Medicine and Allied Sciences, XXXIII(3):254-255.

DOI: https://doi.org/10.1093/jhmas/xxxiii.3.254 


\title{
George Rosen as I Knew Him
}

\author{
ERWIN H. ACKERKNECHT
}

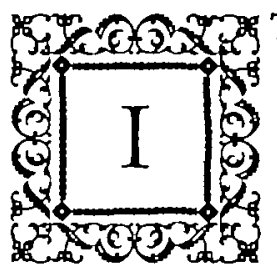

T was a gray Baltimore morning in April 1942 when I first met George Rosen in the Johns Hopkins Institute. We 'clicked' immediately. Being both devotees of medical history we talked for hours almost exclusively about our adored subject; strangely enough neither about our careers (as it behooves colleagues) nor about world politics, though at that moment it breathed heavily down all our necks. I was very much impressed at this furst encounter by George's high intelligence and extraordinary erudition. I was no less impressed by his unassuming and good-tempered ways, which, by the way, he never changed when he rose socially. As intelligence and reading are reflected in his work, which will be discussed by others, I will not expatiate here on this point. Modesty and friendliness survive mostly in personal memories. That is the reason why I have accepted to report mine. I have respected and liked George more than most of my colleagues, but I could not say for which of the four virtues in particular that one finds so rarely combined, I did it.

In my experience George Rosen displayed enormous quantities of equanimity. In spite of the incredible burden of work he always carried, he never seemed rushed, nervous, or impatient. He very rarely was angry. This does not mean though that he was acritical, as is evidenced by some of his book reviews. George's way was certainly never easy, beginning with the necessity of studying in Germany. But he had no talent to be bitter about past difficulties, and he had a fine sense of humor to neutralize bad experiences.

In these early years of our friendship George spent a lot of time in Washington, which fortunately is not far from Baltimore, and he came over frequently to see Sigerist, his great inspiration. In this time falls also the finishing of his perhaps most original and least noticed book, his Specialization of Medicine. In 1946, when George came back from the 
army and Europe, I had moved to New York and I remember vividly our first encounter, wandering with him around the American Museum of Natural History and discussing 'les idéologues.' Though George Rosen was certainly the outstanding social historian of medicine of his generation, this discussion is just one example that he never was a narrow, onesided, provincial specialist.

In the following years we lived just a few blocks away from each other in New York and I was privileged to enjoy Beate's and George's wonderful hospitality. I now only discovered to its full extent George's book collector's ardor-and the extent of his artistic talent. His watercolors were a delight. His excellent choice of illustrations is another evidence of his visual abilities, inherited by his daughter Susan. His enthusiasm for art made him, for instance, undertake a few years ago a tour through Europe, especially southern Germany, to visit the finest baroque churches. George's and Beate's home exhaled harmony and warmth. He was proud of his children, Peter, the pathologist, and Susan, the art historian. He was a devoted son, son-in-law, and brother. I also remember a very pleasant evening spent with him at the place of that unsung pioneer of medical history in the United States, Victor Robinson, to whom he later paid tribute in a fine memorial lecture.

Another commendable trait of George Rosen was that he never was ashamed of his Jewish and Brooklyn origins. He was very much attached to New York City. But there was nothing provincial about this attachment. He was just as able to enjoy other parts of the United States or of Europe. Beate and George visited us in the summer of 1973 in Ascona, one of the most agreeable visits we ever had in our lives. They were such good company. George Rosen was a faithful friend. When my residence at Wisconsin and Zurich made direct contacts rarer, intellectual exchanges never diminished, affectionate attachment never slackened.

George Rosen was so full of energy, of life, and plans, that for days we just could not believe the message that he had died. And we were certainly not the only ones who felt that way. Yet, we must resign ourselves now to the fact that he has left us. But he lives on in his works and the hearts of his family and his grateful friends.

University of Zurich

Zurich 